\title{
International Changes in the Middle East and Their Impact on the Palestinian Cause
}

\author{
Dr. Salwa Farrag \\ Associate Professor of Political Science, \\ Head of the Department of Political Science at Suez Canal University, Ismailia
}

\begin{abstract}
The paper seeks to examine the impact of post 2011 Arab developments on the nation-state and its repercussions on supporting the Palestinian cause? In order to answer that, the study deals with a theoretical approach to the crises of political systems, and then analyzes the nature of developments in the Arab region and its repercussions on the nation-state on the one hand, and its repercussions on the Palestinian cause on the other.It was found through the study that the Palestinian cause is affected by its Arab depth, whether before or after the revolutions. Although the Palestinian cause was not the main title of those revolutions, but it was present in the conscience of the rebellious masses. The Arab countries remained governed in this process by the duality of "the old next to the new" in light of the dilemmas and phenomena that prevailed. It seemed apparent how weak and fragile the Arab national state was towards itself and the Palestinian cause, as it was preoccupied with its internal crises that prevailed over its policies.
\end{abstract}

Keywords: Arab Nations - Palestinian cause - Middle East - International Changes

DOI: $10.7176 / \mathrm{IAGS} / 91-02$

Publication date:August $31^{\text {st }} 2021$

\section{Introduction}

What some Arab countries have witnessed since 2011, from protest movements and popular demonstrations, turned into revolutions that overthrew regimes and governments, and created dilemmas and political phenomena in the Arab region that they did not know, confirms the crises that some Arab regimes are going through.

This is due to the fact that countries that do not have a clear and acceptable mechanism for the transfer of power remain threatened with collapse, and are candidates for popular revolutions, which explains the state of weakness experienced by many Arab countries.

It is worth noting that the developments and transformations that the Arab region has witnessed in the past few years have all marked - remarkably - turning points. Most importantly, these developments clearly embodied the weakness and fragility of the structure of the Arab national state, and its reflection on the support of the Palestinian cause, which is deteriorating day by day. Some of its causes can be traced back to the emergence of the phenomenon of "ideologized" religious organizations in many Arab countries, and the rise of ethnic and sectarian identities, which led to the outbreak of a pattern of armed conflicts and conflicts of a sectarian and ethnic character, especially with a shift in the initial "national" affiliations, which created a state of division that ruptures the unity of the state between discordant subnational interests that divide society vertically across social classes and strata, and external penetrations that strike its security in the heart.

\section{Research Problem:}

Considering the many transformations and changes that the Arab world is witnessing, which is the most changeable and transformative region in the world, with its important international units, different policies, enormous wealth, and conflicting identities, important shifts in the structure of the national state and its external interactions are revealed from time to time, especially towards the political scene of the Palestinian cause, where the cohesion and strength of the Arab state is a key factor for it in order to play its active role towards the central Arab cause, which it has taken upon itself the responsibility of defending since the Palestinian catastrophe in 1948.

The study tried - with objective, neutral visions and away from the difference of Arab and conflicting political systems - to research the extent of the impact of Arab developments on the nation-state and its repercussions on the Palestinian cause, by raising questions about the impact of Arab developments on the nation-state, and the extent to which this reflects on the support of the Palestinian cause. Is the Palestinian cause still a priority for the Arab political regimes? Or is there a setback?

The study does not seek to engage in a debate about the right and wrong aspects of the movement of change in answering it. Rather, the study deals with this thorny issue with objective visions far from adopting intellectual visions of itself, taking all the intellectual visions that are presented.

There is no doubt that the main developments involved a clear paradox between the hope for a new birth of the Arab system after the change that took place in a number of Arab countries in the so-called "Arab Spring" on the one hand - and the frustration generated by the political and security turmoil that followed the situation in 
those countries on the other hand - in addition to the continuity of negative conditions in a number of units of the Arab system.

III. In light of this, we will discuss here the repercussions of these developments on the Arab nationstate, as well as on the Palestinian cause, as follows:

First: A Systematic Theoretical Approach to the Crises of Political Systems:

The state of anxiety of the educated elite in particular and the Arab citizen in general is a product of developments in the entire Arab region in the context of fear and dread of what is happening now and what will happen in the future for the Arab state, which raises the question: to what extent will the crisis of weakness and fragility of the Arab national state go?

In this regard, political science includes several approaches to study the situation of countries experiencing political crises - whether acute or not - and to provide an objective scientific explanation of these crises. Researchers in political science divided these crises that confront these developing countries into five overlapping and intertwined crises, so that every crisis leads to the other where no developing country escapes from it, which can be identified by the following: ${ }^{1}$

1- Identity crisis: This crisis emerges when the state faces a difficulty related to integrating all citizens into a unified framework that brings them together beyond their narrow local affiliations related to language, race and religion. These crises weaken the citizen's belonging to their homeland. It is possible to identify the causes of this crisis in the ethnic, linguistic, class and economic differences, and this situation leads to a loss of confidence in the national identity.

2- Legitimacy Crisis: This crisis is related to the phenomenon of citizens' dissatisfaction with the current political system, and therefore considering it an illegitimate regime. Several factors play a role in bringing citizens to this conviction, including what is related to the nature of authority and the extent to which the government assumes its responsibilities towards the people, in addition to the extent to which the authority respects the constitution.

3- Participation crisis: The political participation of citizens is one of the most important components of political development. It turns into a crisis when citizens are removed from their role in public life. The formal participation in the elections does not mean that the citizen will have a serious contribution to the political life as long as there is a concentration of power for the benefit of the executive authority and a marginalization of the role of the legislative authority.

4- Distribution crisis: This crisis is related to the ability of the political system to a fair distribution of resources, wealth, services, and material and immaterial privileges "security, education, culture, health and social services" as well as the class issue "class struggle", the economy "economic deprivation", and politics "exploitation of power and loss of Integrity", which played an important role in creating the distribution-related crisis.

5- The crisis of penetration: This crisis represents the inability and ability of the political system to penetrate into all areas of the state, and impose its control, which leads to the difficulty of communicating with society and citizens and not benefiting from the government and its projects.

The developments of the political situation in the Arab countries during the past seven years have shown the existence of many crises, problems and dilemmas that threaten the cohesion and strength of the national state, and the reflection of those aforementioned crises on them; It became clear how weak and fragile some Arab countries are. ${ }^{2}$

Second: The Nature of Developments in the Arab Region:

1-Reasons and Motives for Developments in the Arab Region:

What is happening in the Arab region since the beginning of 2011 in the so-called "Arab Spring revolutions" is more interactive, intertwined and ambiguous at all levels. Its movement was popular, in which all segments of society within the state participated in all its concepts, values, principles and religions ${ }^{3}$, focusing on slogans, demands and appeals related to the factors of internal oppression and a clear presence of the causes of internal tension due to external sources, the dependence of the ruling regimes in the Arab Spring countries on Western powers, and the failure of the Arab-Israeli political settlement, and the challenges facing the horizon of the Palestinian cause and its future, especially the escalation of settlement operations in the occupied Palestinian territories and the Judaization of Jerusalem, and the repeated Israeli attacks on the Gaza Strip.

In fact, the imbalance in the demands of the revolutionaries in favor of focusing on the internal affairs of

\footnotetext{
${ }^{1}$ Shiraz Ahmed Al-Najjar, the crisis of state-building in Iraq, to where? Beirut: Center for Arab Unity Studies, The Arab Future, Issue 452, October 2016, pp. 13-11. Najim Meziane, Azmlat Political Development, date of visit 18/1/2017. On the link: www.driouchcity.net/أزمات_التنمية_النباسية a7757.html

${ }^{2}$ The Arab Strategic Report 2013-2014, Cairo: Al-Ahram Center for Political and Strategic Studies, 1st Edition, 2015, p. 143

${ }^{3}$ Abeer Thabet and Imad Mukhaimer, Political Changes in the Gaza Strip after the Israeli Withdrawal and Hamas Movement 2005-2013, Research Presented to the Conference: Gaza Status and Civilization, Al-Quds Open University, Volume 2, January 2015 , p. 252.
} 
Qatar and its grievances raised many questions about the reasons that led to this imbalance, compared to what was the case in the uprisings and revolutions of the fifties and sixties of the twentieth century. Some have recalled how the Arab revolutions fifty years ago were linked to rejecting external pressures, longing to liberation from colonial domination and calling for confronting Israeli ambitions, liberating Palestine and supporting its people. This imbalance was evidence of the current intensification of the popular sense of oppression, tyranny, political dictatorship, appalling class inequality on the social level, the plundering of wealth, the rampant corruption on the economic level, and the violation of the human dignity of citizens by the authorities. $^{1}$

It is clear that the revolutionary tide took on a national dimension, as the protesters did not raise slogans like liberating Palestine, Arab unity, or eliminating Israel. Rather, it was rare for the revolutionaries to chant slogans against Washington and Israel, unlike the case with previous Arab revolutions or coups. While it cannot be overlooked that the Arab nationalist ideology and anti-Israel stances undoubtedly lie in the depth of the Arab mind, they are no longer among the priorities of the masses that have demands of a national nature; Therefore, the absence of Palestine was remarkable. Regardless of the changes that happen in the Arab region: the criminal behavior against Jerusalem and the attacks on the Gaza Strip renew the attractiveness of the Palestinian cause to Arab public opinion.

In general: What unites the revolutions of the Arab Spring and the youth forces that took the lead in the revolutionary action is their lack of an organized revolutionary leadership on the one hand, with a clear integrated revolutionary vision that would allow him to develop scenarios to manage their situation after the Arab Spring on the other hand. Although these revolutions were founded on the shoulders of revolutionary youth, peoples with different sects and tactics joined them. None of the political parties and movements was able to leave its mark on these revolutions ${ }^{2}$. Rather, the forces that jumped to the revolutionary front, and then rose to power - did not have a project for power expressing a clear ideological and intellectual vision of a serious program of governance; this explains the ease with which it has turned into a mere political slogan. Its system lacks the experience of governing and managing state institutions, and their lack of partisan cadres qualified to carry out these missions ${ }^{3}$.

In the absence of a revolutionary leadership framed by a revolution, the exploitation of the Arab Spring revolutions was evident. The masses accomplished the revolution and overthrew rulers and governments, but the leadership in the transitional period was assumed by forces that were not the ones who led the revolution; ${ }^{4}$ Hence, the talk became popular about the deviation of the Arab Spring revolutions from their tracks or attempts to abort these revolutions; the transitional phases that follow revolutions often provide an atmosphere conducive to aborting them through political forces that did not participate in them and may have opposed them ${ }^{5}$.

\section{2-The Results of Developments in the Arab Region:}

The crises that explain the state of turmoil and instability find their presence in the Arab region. The outbreak of revolutions indicates a separating station between the phases before and after the phase of change. This presence comes within the context of a transformational path that, for some, may authorize the fragmentation of countries, considering the patterns of policies and the distribution of forces, the agenda of the regimes and their salient features towards the beginning of the crystallization of new countries whose features are not stable, and their rules are not clear until after a period of time that may be long or short according to the change of dynamics and its speed where the internal, regional and international determinants are intertwined, ${ }^{6}$ bearing in mind that the Arab revolutions have not achieved their main goals, nor have they reached their final stage yet, despite the passage of years since their launch. The focus here will be on the following aspects:

- Continuous instability in the region as a result of the crises that Arab regimes and governments suffer from, whether from the repercussions and waves of the revolutions of change - as happened in Tunisia and Egypt - or as a result of internal disputes between their leaders, as is the case in Yemen, Syria and Libya. The desired process of change and reform and the return of stability in the region requires a time limit estimated by experts for a period of at least five to seven years, given the data of the change movement, and the continuation of the Syrian crisis without a political horizon for its solution. ${ }^{7}$

- The growth of extremist Islamic movements under the dream of establishing the Islamic state, while it was allowed to be fed with money, weapons and equipment by external parties, and to create spaces for

\footnotetext{
${ }^{1}$ Ahmed Youssef Ahmed and Nevin Massad (Editing), The State of the Arab Nation 2011-2012: Dilemmas and Prospects of Change, Beirut: Center for Arab Unity Studies, 1st Edition, May 2012, pp. 193-195

${ }^{2}$ Saeed Refaat, Islamic governance and its internal and external challenges, Cairo: Arab Affairs Magazine (General Secretariat of the League of Arab States), No. 152, Winter 2012, p. 5

${ }^{3}$ Saeed Refaat, Islamic governance and its internal and external challenges, previous reference, p. 7.

${ }^{4}$ Mahmoud Shukair, The Arab Spring Revolutions: Reflections of a Palestinian Leftist, Al-Karmel Magazine, No. 2 , Fall 2011, p. 217.

${ }^{5}$ Bashir Abdel Fattah, Aborting the Arab Revolutions: Egypt and Libya as a Model, Arab Affairs Magazine: (General Secretariat of the League of Arab States), No. 150, Summer 2012, p. 65

${ }^{6}$ Nassif Hita, The Transformational Path of the New Arab Order, Beirut: Institute for Palestine Studies, Issue 93, Winter 2013, pp. 23-24

${ }^{7}$ Walid Abdel Hai, The Arab World 2014 More Disintegration, Al Jazeera Studies Center, January 13, 2014.
} 
their movement in Arab arenas such as Syria, Libya, Yemen and Iraq. Meanwhile, the case of Egypt is exploited - especially in Sinai - to carry out sabotage operations and bloody explosions that suggest a situation of instability.

- A severe political identities crisis manifested itself between Qatari national identities, Arab national identities, and conflicting religious and Islamic identities, not to mention the growing sectarian tendencies, and primary loyalties that were replaced by religion, tribe or ethnicity, while it is one nation with history, religion, geography and culture that incubates identity and belonging ${ }^{1}$.

IV. The Repercussions of Arab Developments on The Nation-State:

The Arab system, whose main features were established in the first part of the twentieth century, has enjoyed some sort of stability and continuity for more than half a century, despite the multiple sources of contradiction and conflict that characterized this system. The colonial powers - through a number of agreements such as Sykes-Picot and the Balfour Declaration - drew a map of the Arab region on the ruins of the Ottoman Empire, and the borders of the countries of the region were demarcated without taking into account the important demographic and geographical factors. The colonial powers laid the foundation of the modern state in many countries of the region by creating administrative, military and economic entities organically linked to the colonial states; this abnormal birth of the state in the Arab region has resulted in several crises, including: the emergence of a number of regional conflict hotspots, such as the Arab-Israeli conflict in the forefront, the IraqiIranian conflict, the conflict over the Western Desert, and a number of border conflicts between many Arab countries in addition to Internal crises between different ethnic, racial and sectarian groups or between ruling elites and peoples.

The Arab state is currently exposed to four main dilemmas that have resulted from developments in the region: -

1- The Dilemma of Political Reform and Democracy:

The events that followed the Arab revolutions established a new era in the Arab countries, as they created a set of variables in the region, but there are difficulties and challenges that come with this change, especially if it is linked to democratic transformation, as long as there are a set of structural obstacles that remain unchanged, such as: the limits of change in the political system, and the continuity of the same conditions that led to the revolution, represented in the various types of exclusion, the closed horizon for the youth, and the new political elites.

These events, as they represented peaceful popular protests that broke the barrier of fear, showed a qualitative shift in the pattern of protests that many of these Arab patterns were unfamiliar with; then the Arab regimes that faced such protests fell into a series of dangerous reactions, as the common logic was leading to violence and luring demonstrators to it. This led the revolution in Libya, Syria and Yemen to turn from a peaceful revolution to an armed revolution, as a result of excessive use of force with which the authorities confronted the demonstrators ${ }^{2}$.

In this context, we recall that since the US occupation of Iraq, the Arab state has been subjected to increasing internal and external pressures to adopt political and democratic reforms that lead to the release of political and civil liberties and the freedom to form parties, associations and unions, and to put in place guarantees that guarantee the integrity of elections and freedom of the press and media. Even countries that have allowed greater pluralism Political parties, such as Egypt, Jordan, and Morocco, also relied on a system of legal, security and administrative tools in order to control parties, media, and civil society organizations under the circumstances of the current stage, which led citizens to stay away from participating in the political process and to the weakness of political parties and civil society organizations ${ }^{3}$.

Based on the foregoing: it becomes clear to the researcher that democracy in the majority of Arab regimes that advocate it is not an expression of the nation's will as much as it is a response - in the positive and negative concept of response - to external requirements, and it is not necessarily an expression of the availability of a culture of democracy ${ }^{4}$.

2- The Dilemma of Development and Social Justice:

The exacerbation of economic and social problems, widespread corruption, and the monopolization of development revenues by narrow elites linked to power led to an increase in political and social discontent and the emergence of protest movements on a large scale in many Arab countries, due to the difficulty of solving the

\footnotetext{
${ }^{1}$ Nadia Saad El-Din, What future for regional systems in an environment of instability? Cairo: Al-Ahram Center for Political and Strategic Studies, International Politics, Supplement, No. 197, Volume 49, July 2014, pp. 22 and 23.s

${ }^{2}$ Abdelilah Belkeziz (Editing and Presentation), Change in the Arab World, What Outcome? Beirut: Center for Arab Unity Studies, 1, 2013, pp. 24-27.

${ }^{3}$ The Arab Strategic Report 2010, Cairo, Al-Ahram Center for Political and Strategic Studies, 1, 2011, p. 155.

${ }^{4}$ Ibrahim Abrash, The Arab Revolutions and the Palestinian Cause: An Analytical Study of the Arab Revolutions and Their Impact on the Palestinian Cause, Gaza: The Palestinian Planning Center, Strategic Readings, Issue 7, April 2011, pp. 40-43
} 
semi-chronic economic problems in Arab economies represented by unemployment. The low level of per capita income for large groups, the poor distribution of wealth, the existence of an economic structure that depends on fragile sectors, such as tourism and services, and the decline in the pace of industrialization compared to the seventies of the last century, in addition to the fact that the economy in the Arab countries is characterized by bloated bureaucratic management, and the state's control over many of its sides; this creates an important challenge in the democratic ${ }^{1}$ transition before the Arab national state.

This led to the disruption of the social contract between society and the state in the Arab world, which was the mainstay of the stability of the ruling regimes. This helped escalate the demands for political reform and the achievement of social justice and the increase of social and economic protest movements that overthrew a number of political regimes during the past years. ${ }^{2}$

\section{3- The Dilemma of National Integration:}

What emerged from the current situation and developments in the Arab world: Arab countries are exposed to the escalation of subsidiary identities at the expense of national identity, especially in those countries that enjoy a high degree of racial, religious and ethnic diversity. This phenomenon has resulted from several different factors, foremost among which is the Arab political regimes for decades withholding cultural freedoms and depriving different groups of the right to freely express their identity, culture and faith, as happened in the case of the Kurds in Iraq, and the case of the Berbers in North Africa. The ruling elites in the Arab world also tried to impose the Arab cultural identity on other groups through the dominant educational and media system ${ }^{3}$. Just as the population is one of the elements of the state's power, they may also be one of the reasons for its destruction and elimination, if differences aggravate among them and the conflict and fighting intensifies with national disharmony and the outbreak of ethnic, tribal and religious conflict, civil wars erupt among them, while foreign interventions are active. ${ }^{4}$ When we talk about the state, we mean its people and its territory as the cornerstone of its establishment; therefore, the concept of the national state is based on three concerted elements: the "unity of the land", the "homogeneity of the people" and the existence of a "comprehensive national project based on the idea of liberation and independence".

Ethnic and religious minorities in the Arab world have often been subjected to discriminatory practices that have affected their political and economic status as well, as happened in the case of the Christians of Southern Sudan, and the case of the Shiites in Iraq and Lebanon, where the channels of political participation were blocked and political and civil liberties were restricted. These groups were prevented from legitimately and legally expressing their demands. This caused its abrogation of the national group, its circumvention of its subsidiary identities, its tendency to separate from the central state, and the quest for the formation of a new state, as happened in the case of Sudan with external support. ${ }^{5}$

\section{4- The Dilemma of Penetration and External Interference:}

This dilemma is related to the escalation of the role of international and regional actors in the internal policies of the countries of the region during the past few years. External interference is not new to the Arab region, but what is new is that these regional and international powers worked to reshape the map of alliances in the region and supported initiatives that undermine the stability of the existing Arab regime in general and its countries in particular. ${ }^{6}$

It is worth noting that external interference in the internal affairs of states in the contemporary reality is not limited to direct intervention, but may be carried out by indirect means and tools, including media pressure, the employment of pressure groups inside the country as the human rights group, and the financing and training of some civil society organizations and political parties on the work of mass mobilization and pressure on regimes. The effectiveness of such indirect means has increased as a result of the amazing development in communication technologies and information systems, and their impact was clear in the Arab countries that witnessed popular revolutions. $^{7}$

\footnotetext{
${ }^{1}$ Abdel Qader Abdelali, New Change in the Arab World and Opportunities for Democratic Transformation, in: Abdelilah Belkeziz (Editing and Presentation), Change in the Arab World, What is the outcome? Previous reference, pg. 29-30

David's, Sorenson, Transition in the Arab World: Spring or Fall, Strategic studies Quarterly, Fall2011, PP33-34.

${ }^{2}$ Arab Strategic Report 2010, previous reference, p. 156.

${ }^{3}$ Arab Strategic Report 2010, previous reference, p. 156.

${ }^{4}$ Omar Ahmed Kaddour, The Form of the State and Its Impact on the Organization of Security Facility, Cairo: Madbouly Library, 1, 1997, p. 147.

${ }^{5}$ Arab Strategic Report 2010, previous reference, p. 156,157. Suzy Mohamed Abdel Aziz, Non-state actors: patterns and nature of influence, a theoretical study, Cairo: Al-Ahram Foundation, Journal of Democracy, No. 60, October 2015, p. 29, Abdelilah Belkeziz (Editing and Presentation), Change in the Arab World, what is the outcome? Previous reference, pg. 26-27.

${ }^{6}$ Ahmed Mukhtar El-Gamal, Contemporary Political Encyclopedia: Episode 27, Cairo: Arab Affairs (General Secretariat of the League of Arab States), No. 156, Winter 2013, pp. 137 and 138.

${ }^{7}$ Ahmed Youssef Ahmed and Nevin Massad (Editing), The State of the Arab Nation 2011-2012: Dilemmas of Change and its Prospects, previous reference, pg. 40 .
} 
V. The Arab developments also produced many phenomena that helped in the weakness and fragility of the state, as the future of the region depends to a large extent on the failure or success of the countries in the region in dealing with these phenomena:

\section{1- Boundary Flow Phenomenon:}

The borders that surround the Arab countries, especially in the post-revolution phase, are no longer capable of staving off dangers and preventing threats from reaching the depths of the Arab countries. Rather, they have become soft borders. This has contributed to the exacerbation of border security problems in the region and the continued cracking of the state's structure in light of the overlapping of internal transformations and regional interactions. The conflict between the state and cross-border terrorist groups has become clear - in many cases - the focus of new crises and challenges ${ }^{1}$, with its risks to the state entity: the emergence of what is known as a state that does not control parts of its territory (ungovernable).

\section{2- The Growing Phenomenon of Terrorism:}

The intensity of cross-border movement has led to an increase in the penetration of societies and their exposure to threats by armed violence groups, in addition to facilitating the capabilities of terrorist groups to target vital institutions within the state. Jordan, for example, was subjected to many terrorist attempts through the movement of refugees to carry out terrorist operations during 2014. This resulted in security threats to Arab countries, including Egypt, which witnessed many terrorist attacks executed by terrorist organizations, and Sinai makes a good example ${ }^{2}$.

The Arab countries have witnessed a major role for religious organizations, such as the Muslim Brotherhood, Hezbollah, the Islamic State organization "ISIS" in Iraq and Syria, and the Ansar Allah group "Houthis" in Yemen. This role acquires its importance and influence due to its destabilizing activities in countries, and also by relationships between these organizations and states; this made them appear as new tools to implement the policies of their sponsoring countries, whether with funding, military supplies, or propaganda and directed media ${ }^{3}$.

We note that the phenomenon of non-state actors, with their military wings, has now possessed military capabilities comparable to - if not greater than - the regular armies, in a way that enables them to delegate the requirements of the state's monopoly on the legitimate use of force to confront security threats. The ongoing transformations have highlighted the importance of these actors in relation to the countries involved in the Arab conflicts, or those who benefit from them ${ }^{4}$.

\section{3- The Growing Phenomenon of Sectarianism:}

The sectarian issue, with its sectarian, religious and ethnic dimensions, is one of the important entrances to understanding the political geography of the Arab world, especially at this stage (the Arab revolutions). From the east to the west, this issue almost represents one of the points of tension, not only within the countries and societies of the region, but also among them. From here, we must consider the strategic dimensions of the sectarian issue, which is like a powder keg that can be ignited at any time. It can be said that the Arab regimes failed to resolve the sectarian issue internally, which paved the way for its external use ${ }^{5}$.

Based on the foregoing: It can be noted that sectarian issues have been raised prominently in more than one Arab country, starting with Lebanon - where there are issues with Copts, to the Arab Gulf states - where the Shiite issue is in Bahrain, Kuwait, and Saudi Arabia.

\section{4- The Phenomenon of Non-State Actors:}

The cracking of the structures of society in the Arab countries constituted one of the most dangerous manifestations of the crisis and its current complexities, which reflected a failure in managing crises and the way to deal with them. It also revealed the historical defect in the political development process that was led by the ruling regimes in the previous decades. Since the national structure was not immune in a scientific and institutional way to face such pressures ${ }^{6}$, its structures were fractured in the face of this polarization situation, which led to a major social division.

In this context, the phenomenon of non-state actors has emerged with their military wings, as they now possess military capabilities comparable to - if not superior to - the regular armies, in a way that enables them to undermine the requirements of the state's monopoly on the legitimate use of force to confront security threats. The ongoing transformations have highlighted the importance of these actors for the countries involved in the Arab conflicts, or the beneficiaries of them, and they have an impact on the region's

\footnotetext{
${ }^{1}$ Arab Strategic Report 2013-2014, previous reference, p. 319.

${ }^{2}$ Previous reference, p. 329

${ }^{3}$ Dalal Mahmoud El-Sayed, The Spread of Power and the Limits of Changing the Balance of Regional Powers, Cairo: Al-Ahram Center for Political and Strategic Studies, International Politics: Examining Theoretical Attitudes, Issue 200, Vol. 50, April 2015 , p. 15.

${ }^{4}$ Mai Mujib, Regional System... Sources of Change and Identity Controversy, Cairo: Al-Ahram Center for Political and Strategic Studies, International Politics: Theoretical Attitudes Supplement, Issue 200, Volume 50, April 2015, pg. 7.

${ }^{5}$ Previous reference, p. 120.

${ }^{6}$ Mohamed Bassiouni Abdel Halim, Cross-border Terrorism... Patterns and Motivations, Cairo: Al-Ahram Center for Political and Strategic Studies, International Politics: Theoretical Attitudes Supplement, Issue 201, Volume 50, July 2015, p. 11.
} 
interactions, stability and security ${ }^{1}$.

It has also been associated with the rise of ethnic and sectarian identities, in addition to resorting to violence through the increase in identity conflicts between races, sects, and ethnicities. The danger of this type of conflict is that it can vertically divide the whole society from top to bottom, across classes and social strata because it is a conflict related to language, religion, and sect, which are struggles for existence and survival. Its danger increases if the identity conflict is mistaken for economic and political reasons ${ }^{2}$. In this field, writings and analyses about the Sunni-Shiite conflict spread once in Iraq, another in Syria, and thirdly in Lebanon, while this analysis ignores the fact that these ethnicities lived for decades in peace with each other, and their children participated in the national movements demanding independence; this affects the Arabs' view of themselves, and deepens the causes of division and fragmentation on sectarian grounds. As for thinking about how to confront these dilemmas and phenomena, it is necessary for all the Arabs - especially the big countries - to put the importance of launching an Arab-Arab reconciliation process without delay, to be patient with our difficulties and start removing the obstacles that prevent them, and to realize the gravity of the situation without it, identifying the potential, apparent, near or far threats that affect the existence of the Arab entity or its strategic interests ${ }^{3}$.

\section{The Repercussions of Arab Developments on the Palestinian Cause:}

Since its inception, the "Palestinian cause" has been governed by regional and international balances, and its status has been steadily shifted backwards with the decline in the balance of Arab power towards the region and the world. The "Palestinian cause" has been transformed from the "central Arab issue" since 1948 to a prerequisite for a comprehensive Arab-Israeli settlement after 1967, and then to a part of the procession of "disengagement" between Egypt and Syria on the one hand and the Israeli occupation state on the other hand. Despite the decline in the Arab role, the Palestinian-Israeli conflict remained present formally as one of the permanent items of the decisions of the Arab summits. With the erosion of the Arab regional system in 1990 following Iraq's occupation of Kuwait, the door opened to settling the Palestinian-Israeli conflict as a justification for completing a comprehensive Arab-Israeli normalization. Regional and international developments played a role in the consolidation of this idea, as the Palestinian cause turned into a means in Arab-Iranian regional disputes under the slogan "Solidarity with the Cause" since the mid-1990s, and later in Arab-Turkish relations since the arrival of Hamas to the government in 2006, and then in the Freedom Flotilla incident in 2010, under the slogan of "solidarity with Gaza"4

\section{1- The Palestinian Position on Arab Developments:}

The state of the Palestinian division affected the Palestinian position on the Arab developments, as it was divided against itself according to the interests of the two Palestinian parties: In the West Bank, the Palestinian Authority understood the importance of the strategic shifts produced by the Arab Spring and their repercussions on its relationship inside the Palestinian territories and in the Arab, regional and international environment, dealt with it with great caution, and worked to divert its internal course towards achieving Palestinian reconciliation and the establishment of a Palestinian state. It also adopted a policy of deliberation to spare the Palestinian communities in the Arab countries the scourge of wrong decisions and calculations. For President Mahmoud Abbas, the Palestinian National Authority and the Fatah movement, the Arab Spring resulted in the fall of an ally that had long been reliable in Cairo, especially at the beginning of the Arab Spring, the erosion of Palestinian faith in negotiations, and the bitter disappointment in US President Barack Obama. The Arab Spring was an opportunity to reconsider the strategic directions, to turn to the United Nations to deal with the Israeli occupation, ${ }^{5}$ and to obtain a non-member observer state at the United Nations.

As for the Gaza Strip, Hamas expressed its vision for the Arab Spring revolutions as follows: ${ }^{6}$

- It is a great and important development on the road to liberating Palestine and confronting the Zionist project.

- There is no doubt that the Arab Spring increased Israeli anxiety and confused its calculations, because the rules of the game to which the enemy was accustomed started to change.

\footnotetext{
${ }^{1}$ Mai Mujib, The Regional System... Sources of Change and Identity Controversy, previous reference, p. 7.

${ }^{2}$ Ali El-Din Hilal, The Arab Regional Order in the Face of the Dangers of Division and Sectarianism, Cairo: Al-Ahram Center for Political and Strategic Studies, International Politics, No. 198, Volume 49, October 2014, p. 44.

${ }^{3}$ See: Nasr Muhammad Aref, Reform, Reconciliation, Reconciliation: A Study in the Knowledge Bases of Arab Interest, Muhammad Safi Kharboush (Editing), Arab Reconciliation: Visions - Mechanisms - Prospects for Success, Center for Research and Political Studies - Faculty of Economics and Political Science: Cairo University, 1995, p. 63.

${ }^{4}$ Mustafa al-Labbad, Arab Politics towards the Palestinian Issue between Absence and Collusion, Beirut: Institute for Palestinian Studies: Journal of Palestinian Studies, Issue 108, Fall 2016, pp. 100-104.

${ }^{5}$ International Crisis Group, Palestinian Reconciliation: Movement but Stalemate, Amman: Center for Middle East Studies, Middle East Report No. 110, 20 July 2011

${ }^{6}$ Speech of Head of the Political Bureau Khaled Meshaal at the Conference of Islamists in the Arab World and the Palestinian Issue in the Light of Arab Changes and Developments, Beirut: Al-Zaytouna Center for Studies and Consultations, 29/28 November 2012.
} 
- There is no doubt that the Arab Spring and the changes in the Arab world give the Palestinian resistance parties and movements an opportunity to work in an Arab environment that is more in line with the resistance line and more adherent to the Palestinian national principles and rights.

- $\quad$ The Arab Spring and its successive major events changed the map of Hamas' political relations, adding to it and affecting some of them.

It is clear that the position of the Hamas movement towards the Arab Spring reveals pragmatic political and partisan calculations that reflect the nature of the ambivalence of positions. Hamas supported the Tunisian Spring from its beginnings, and in the Egyptian case, Hamas was more supportive, as was the Libyan case, but its position differed from the crisis in Syria, based on the fact that Damascus is the permanent headquarters of the leadership of the Political Bureau - The movement's position changed in favor of the opponents of President Bashar al-Assad's regime in Syria ${ }^{1}$, ignoring the impact of this on Palestinian national interests.

In the same context: Hamas continued to bet excessively on the Arab Spring until the former president, with Muslim Brotherhood affiliation, Mohamed Morsi, was removed from power, and the military institution took over the administration of the country, backed by popular support. Then, relations became tense and remained that way after the election of President Abdel Fattah El-Sisi ${ }^{2}$. Despite the position of Hamas, Chekka cannot undermine Egypt's commitment to the Palestinian cause and its firm positions in this context. This is confirmed by Egypt's position regarding three wars launched by Israel on the Gaza Strip, and Cairo was the sponsor of the truce ${ }^{3}$.

\section{2- Arab Developments from Israel's Perspective:}

The extreme right-wing governments, which have been at the fore in the Israeli political scene for more than twenty years, have contributed to perpetuating the religious character of the conflict, especially after targeting Jerusalem, Al-Aqsa Mosque and some mosques in other areas of Palestine, and warnings of that are still being made ${ }^{4}$. The Israeli practices in Jerusalem, in particular, also allowed the intervention of regional parties and non-Arab neighboring countries in the equation of the conflict between Israel and the Palestinians, such as Iran and Turkey.

While the Israeli vision came from the Arab developments in the annual report of the Israeli national security, it refers to three main events as determinants of the relationship between Israel and the Arab countries:

1- The Houthis rebellion in Yemen, backed by Iran, against power.

2- The Russian intervention in Syria by forming an alliance with Iran, the Syrian regime and the Lebanese Hezbollah.

3- Iran nuclear deal with international powers.

The report shows that there is a common interest between Israel and the Sunni Arabs due to the emergence of Iran's growing power in the region, especially in Syria, Iraq and Yemen, and the Saudi reaction to this expansion through military intervention, as well as through the support of the Arab Gulf states for the Sunnis most distant from the events by providing the military war with material and political support. According to analysts interested in the Iranian issue, the Arab opposition to a public discussion with Israel has diminished than before ${ }^{5}$.

It is noticeable that the Israeli threats are less talked about at the present time, in light of the current developments in the region, but Israel will continue to pose a security challenge to the Arab countries. The Israeli security and military doctrine consider any threat to it an existential danger, and therefore it considers any positive development in the Arab countries to be a threat to it.

With the Arab developments and the Arab republics' noninfluential role due to the aforementioned internal conditions, the rudder of influence shifted to the Arab Gulf states within what remained of the formal Arab regional structures, and because Iran poses - from the Gulf perspective - the greatest threat to the ruling Gulf regimes, coordination with the Israeli occupation state, without preconditions related to the settlement of the Palestinian issue, has turned into a declared Gulf policy that is expected to escalate in the next stage ${ }^{6}$.

We can note from what has been previously stated that the developments in the Arab arena have greatly affected the Palestinian cause and the conflict with the Israeli enemy. The most important features of these repercussions can be monitored as follows:

1- The Arab countries are withdrawing to solve their complex internal problems, whether they are

\footnotetext{
${ }^{1}$ Ahmed Youssef Ahmed and Nevin Massad (Editing), The State of the Arab Nation 2012-2013: The Future of Change in the Arab World: Imminent Dangers, Beirut: Center for Arab Unity Studies, 1st Edition, April 2013, p. 119.

2 Arab Strategic Report 2011-2012, Al-Ahram Center for Political and Strategic Studies, 2013, p. 274.

${ }^{3}$ Jamal al-Baba, Egypt's relationship with the Gaza Strip and the recent Israeli aggression 2014, Gaza: The Palestinian Planning Center - the Palestine Liberation Organization, Journal of the Palestinian Planning Center, Issue 42-43, July-October 2014, pp. 125-128.

${ }^{4}$ Ghazi Al-Arifi, Between the Knesset and the Synagogue, Al-Ittihad Emirati newspaper, November 22, 2014.

${ }^{5}$ See: Shlomo Brom and Anat Cruz and others, Strategic Report of the Israeli Institute for National Security Studies for the year 2014-2015,

Tel Aviv: Institute for National Security Studies, translation: Roya Center for Studies and Research - Gaza, 2016.

${ }^{6}$ Mustafa Al-Labbad, Arab Politics towards the Palestinian Diya between Absence and Collusion, previous reference, pp. $100-104$.
} 
political, security, economic or social ${ }^{1}$. Hence, the Palestinian cause and the conflict with the Israeli occupation are no longer at the forefront of these countries' internal and external policies.

2- The problems of the Arab countries increased as a result of the repercussions of the Arab Spring, which affected some of them. The Arab world is geographically interconnected; As a result, the countries that the winds of change did not hit directly, have reached them indirectly through neighborhoods and borders ${ }^{2}$.

3- The Arab peoples have been affected by the Arab Spring and the instability they are going through. Their interests are limited to building a ruling system characterized by democracy, freedom of expression, guaranteeing human rights, achieving social justice, equitable distribution of wealth, and improving the standard of living; Hence, the Palestinian issue no longer occupies the same position that it had among the Arab peoples ${ }^{3}$.

4- Israel took advantage of the neglection of the Palestinian cause among Arab governments and peoples; it succeeded in its aggressions, thwarted all peace initiatives, and continued its aggression, settlements, Judaization of Jerusalem and the attempt to divide the courtyards of Al-Aqsa Mosque. It also continued arrests, killings, raids, and land seizures without taking the international and humanitarian law and the Charter of the United Nations into account, being indifferent to the resolutions of international legitimacy and the Arab nation ${ }^{4}$.

5- Iran and Turkey's ambitions for influence and control, and their interference in the affairs of some Arab countries and the Palestinian cause, following the rise of the Islamic tide in the region, have exacerbated the problems facing the Arab countries. The role of Iran in Iraq, Syria, Lebanon, Yemen and Bahrain has become clear ${ }^{5}$.

6- Arab countries are turning to non-Arab countries in order to help solve their internal problems. The assistance they provide to strengthen the structure of the ruling regime ${ }^{6}$, and the demands of the Arab countries are no longer limited to the demand for an end to the Israeli occupation of the land of the State of Palestine, which became an observer member of the United Nations on November 29, 2012. Rather, there are other demands that take precedence over the demands of the national cause.

Although Palestine was not the main title of those revolutions, it was in the conscience of the revolting Arab masses. The nation hopes that this revolutionary movement will contribute to the establishment of a new, coherent Arab official system that will change the circumstances of the conflict with the Zionist enemy in the interest of the Palestinian cause ${ }^{7}$.

Despite the complex developments and the Palestinian division, the active political movement of the Palestinian leadership in various countries of the world, and the explanation of the cause, earned the cause great international support that appeared through voting in international institutions, and achievements were made such as:

- Acceptance of the State of Palestine as an observer member of the United Nations on November 29, 2012, with its borders on the line of June 4, 1967, with East Jerusalem as its capital, and the right of return of refugees under United Nations Resolution 194, without prejudice to the status of the Palestine Liberation Organization, where Palestine obtained 138 votes to 9 opposing votes. Nations ${ }^{8}$.

However, Palestine was not able to fully benefit from this achievement as a member of the United

- In September 2015, the United Nations adopted a resolution allowing the Palestinians to raise their flag at the headquarters of the international organization in New York. The resolution was adopted by 119 votes in favor and eight countries opposed, including Israel and the United States, while 45 countries abstained from voting to raise the Palestinian flag in front of the official headquarters of the United Nations, including in Geneva and Vienna. This constitutes a new recognition that affirms the legitimate rights of the Palestinian people to establish their independent state with East Jerusalem as its capital.

- $\quad$ On December 23, 2016, the UN Security Council overwhelmingly approved a resolution calling on Israel to stop settlements in the occupied Palestinian territories. The resolution affirms the illegality of Israel's

\footnotetext{
${ }^{1}$ Abeer Thabet and Imad Mukhaimer, Political Transformations in the Gaza Strip after the Israeli Withdrawal and Hamas Movement 20052013, previous reference, p. 250.

${ }^{2}$ Barakat Al-Farra, The Repercussions of the Arab Environment on the Palestinian Issue, previous reference, p. 133.

${ }^{3}$ Ibrahim Abrash, The Arab Revolution and the Palestinian Cause: An Analytical Study of the Arab Revolts and Their Impact on the Palestinian Cause, previous reference, p. 86.

${ }^{4}$ Ahmed Jamil, 2012 Gaza Party and the State: The Inability to Change the Rules of the Game, previous reference, p. 135.

${ }^{5}$ Mustafa Al-Labbad, Arab Politics towards the Palestinian Issue between Absence and Collusion, previous reference, pp. $100-104$.

${ }^{6}$ Barakat Al-Farra, The Repercussions of the Arab Environment on the Palestinian Issue, previous reference, p. 132.

${ }^{7}$ Abeer Thabet and Imad Mukhaimer, Political Transformations in the Gaza Strip after the Israeli Withdrawal and Hamas Movement 2005 2013, previous reference, p. 250.

${ }^{8}$ Barakat Al-Farra, The Repercussions of the Arab Environment on the Palestinian Issue, previous reference, p. 133.
} 
establishment of settlements in the Palestinian territories occupied since 1967, including East Jerusalem. The establishment of settlements is a flagrant violation under international law and a major obstacle to achieving the two-state solution and establishing a just peace. The resolution also called for an immediate cessation of all settlement activities on the occupied Palestinian lands, and made clear that any changes to the 1967 borders would not be recognized without the agreement of the two parties. The resolution emphasized discrimination in dealings between Israel and the territories occupied in 1967. The resolution was passed by 14 votes (out of 15 ), with the United States abstaining ${ }^{1}$.

\section{Conclusion}

It was found through the study that the Arab developments resulted in more crises and dilemmas that clearly embodied the weakness and fragility of the structure of the Arab national state. Some of them could be attributed to the emergence of the phenomenon of "ideologized" religious organizations in many Arab countries, and the rise of ethnic and sectarian identities, which led to the outbreak of a pattern of armed conflicts and conflicts of a sectarian and ethnic nature, especially with a shift in the primary "national" affiliations which created a state of division that tore the bonds of the one state between discordant sub-national interests that divided society vertically through social classes and strata, and external penetrations that have continued to strike its security in the heart.

We can also note the decline of the traditional sources of support for the Palestinian side, the most important of which is Arab support, resulting from Arab developments and regional and international changes; therefore, it is not expected that real positive changes will occur in Arab positions on the Palestinian cause.

\section{Findings:}

- The Palestinian cause affects - and is permanently affected - by the Arab neighborhood, as it was and still is in light of the Arab developments whose chapters have not yet been completed.

- It is clear that Palestine was not the main title of those revolutions, but it was in the depth and conscience of the revolting Arab masses.

- The Arab context has been governed by the dualism of "the survival of the old alongside the new" in light of the dilemmas and phenomena that prevailed in the dichotomy of the new and the old, the new with what it went through, and the old with fear of the wave developments.

- The Palestinian cause, despite all the twists and turns it has gone through, remains the basis of the ArabIsraeli conflict, and without a just solution, this conflict will not end.

- Any decision regarding Palestine will not be possible for the Palestinians to take without obtaining Arab and Islamic support because of Palestine's uniqueness in the region as a whole.

\section{Recommendations:}

- The necessity of reconsidering the political culture prevailing in Palestine, and reformulating the Palestinian political awareness and the culture of the national liberation movement so that it is not limited to the liberation of the land, but to include the values of justice, equality, democracy and the quality of life, by examining the impact of the Arab revolutions and the causes of their outbreak.

- The necessity of unifying Palestinian strategies and goals through the development and activation of the Palestine Liberation Organization as the representative of the Palestinian people.

- The necessity of patience in Palestinian decision-making regarding the events taking place in our Arab environment.

- Preserving the independent Palestinian decision and not depending on it in regional or international alliances that may increase the situation of asylum and displacement, with the need to work on restoring the real status of the Palestinian cause in its Arab, regional and international environment.

\section{References}

Abdelilah Belkeziz (Editing and Presentation), Change in the Arab World, What Outcome? Beirut: Center for Arab Unity Studies, 1, 2013.

Abdel Qader Abdelali, New Change in the Arab World and Opportunities for Democratic Transformation, in: Abdelilah Belkeziz (Editing and Presentation), Change in the Arab World, What is the outcome?

Abeer Thabet and Imad Mukhaimer, Political Changes in the Gaza Strip after the Israeli Withdrawal and Hamas Movement 2005-2013, Research Presented to the Conference: Gaza Status and Civilization, Al-Quds Open University, Volume 2, January 2015.

Ahmed Mukhtar El-Gamal, Contemporary Political Encyclopedia: Episode 27, Cairo: Arab Affairs (General

${ }^{1}$ Saeb Erekat: The Security Council's adoption of the resolution to stop settlements is a victory for hope and peace, Palestinian News and Information Agency, Wafa, on December 23, 2016, at the link: http://www.wafa.ps/ar page.aspx?id=nbqGEqa730363831164anbqGEq s 
Secretariat of the League of Arab States), No. 156, Winter 2013.

Ahmed Youssef Ahmed and Nevin Massad (Editing), The State of the Arab Nation 2011-2012: Dilemmas and Prospects of Change, Beirut: Center for Arab Unity Studies, 1st Edition, May 2012.

Ali El-Din Hilal, The Arab Regional Order in the Face of the Dangers of Division and Sectarianism, Cairo: AlAhram Center for Political and Strategic Studies, International Politics, No. 198, Volume 49, October 2014.

Arab Strategic Report 2010, previous reference, p. 156,157. Suzy Mohamed Abdel Aziz, Non-state actors: patterns and nature of influence, a theoretical study, Cairo: Al-Ahram Foundation, Journal of Democracy, No. 60, October 2015.

Arab Strategic Report 2011-2012, Al-Ahram Center for Political and Strategic Studies, 2013.

Arab Strategic Report 2013-2014, Cairo: Al-Ahram Center for Political and Strategic Studies, 1st Edition, 2015.

Barakat Al-Farra, The Repercussions of the Arab Environment on the Palestinian Issue,

Bashir Abdel Fattah, Aborting the Arab Revolutions: Egypt and Libya as a Model, Arab Affairs Magazine: (General Secretariat of the League of Arab States), No. 150, Summer 2012.

Dalal Mahmoud El-Sayed, The Spread of Power and the Limits of Changing the Balance of Regional Powers, Cairo: Al-Ahram Center for Political and Strategic Studies, International Politics: Examining Theoretical Attitudes, Issue 200, Vol. 50, April 2015.

David's, Sorenson, Transition in the Arab World: Spring or Fall, Strategic studies Quarterly, Fall2011.

Ghazi Al-Arifi, Between the Knesset and the Synagogue, Al-Ittihad Emirati newspaper, November 22, 2014.

Ibrahim Abrash, The Arab Revolutions and the Palestinian Cause: An Analytical Study of the Arab Revolutions and Their Impact on the Palestinian Cause, Gaza: The Palestinian Planning Center, Strategic Readings, Issue 7, April 2011.

International Crisis Group, Palestinian Reconciliation: Movement but Stalemate, Amman: Center for Middle East Studies, Middle East Report No. 110, 20 July 2011.

Jamal al-Baba, Egypt's relationship with the Gaza Strip and the recent Israeli aggression 2014, Gaza: The Palestinian Planning Center - the Palestine Liberation Organization, Journal of the Palestinian Planning Center, Issue 42-43, July-October 2014.

Khaled Meshael, Speech of Head of the Political Bureau Khaled Meshaal at the Conference of Islamists in the Arab World and the Palestinian Issue in the Light of Arab Changes and Developments, Beirut: Al-Zaytouna Center for Studies and Consultations, 29/28 November 2012.

Mahmoud Shukair, The Arab Spring Revolutions: Reflections of a Palestinian Leftist, Al-Karmel Magazine, No. 2, Fall 2011, p. 217

Mai Mujib, Regional System... Sources of Change and Identity Controversy, Cairo: Al-Ahram Center for Political and Strategic Studies, International Politics: Theoretical Attitudes Supplement, Issue 200, Volume 50, April 2015.

Mohamed Bassiouni Abdel Halim, Cross-border Terrorism... Patterns and Motivations, Cairo: Al-Ahram Center for Political and Strategic Studies, International Politics: Theoretical Attitudes Supplement, Issue 201, Volume 50, July 2015.

Mustafa al-Labbad, Arab Politics towards the Palestinian Issue between Absence and Collusion, Beirut: Institute for Palestinian Studies: Journal of Palestinian Studies, Issue 108, Fall 2016.

Nadia Saad El-Din, What future for regional systems in an environment of instability? Cairo: Al-Ahram Center for Political and Strategic Studies, International Politics, Supplement, No. 197, Volume 49, July 2014.

Najim Meziane, Azmlat Political Development, date of visit 18/1/2017. On the link: www.driouchcity.net-أزمات a7757.html

Nasr Muhammad Aref, Reform, Reconciliation, Reconciliation: A Study in the Knowledge Bases of Arab Interest, Muhammad Safi Kharboush (Editing), Arab Reconciliation: Visions - Mechanisms - Prospects for Success, Center for Research and Political Studies - Faculty of Economics and Political Science: Cairo University, 1995

Nassif Hita, The Transformational Path of the New Arab Order, Beirut: Institute for Palestine Studies, Issue 93, Winter 2013.

Omar Ahmed Kaddour, The Form of the State and Its Impact on the Organization of Security Facility, Cairo: Madbouly Library, 1, 1997

Saeed Refaat, Islamic governance and its internal and external challenges, Cairo: Arab Affairs Magazine (General Secretariat of the League of Arab States), No. 152, Winter 2012.

Saeb Erekat: The Security Council's adoption of the resolution to stop settlements is a victory for hope and peace, Palestinian News and Information Agency, Wafa, on December 23, 2016, at the link: http://www.wafa.ps/ar page.aspx?id=nbqGEqa730363831164anbqGEq

Shiraz Ahmed Al-Najjar, the crisis of state-building in Iraq, to where? Beirut: Center for Arab Unity Studies, The Arab Future, Issue 452, October 2016.

Shlomo Brom and Anat Cruz and others, Strategic Report of the Israeli Institute for National Security Studies for 
the year 2014-2015, Tel Aviv: Institute for National Security Studies, translation: Roya Center for Studies and Research - Gaza, 2016.

Walid Abdel Hai, The Arab World 2014 More Disintegration, Al Jazeera Studies Center, January 13, 2014. 